九州大学学術情報リポジトリ

Kyushu University Institutional Repository

High-pressure torsion of pure metals :

Influence of atomic bond parameters and stacking fault energy on grain size and correlation with hardness

Edalati, Kaveh

Department of Materials Science and Engineering, Faculty of Engineering, Kyushu University

Horita, Zenj i

WPI, International Institute for Carbon-Neutral Energy Research (I2CNER), Kyushu University

http://hdl. handle. net/2324/25601

出版情報：Acta Materialia. 59 (17)，pp.6831-6836，2011-10-17. Elsevier バージョン :

権利関係 : (C) 2011 Acta Materialia Inc. 
Acta Materialia 59 (2011) 6831-6836

Received 11 April 2011; received in revised form 31 May 2011; accepted 21 July 2011.

Available online 17 August 2011.

\title{
High-pressure torsion of pure metals: Influence of atomic bond parameters and stacking fault energy on grain size and correlation with hardness
}

\author{
Kaveh Edalati*, Zenji Horita
}

Department of Materials Science and Engineering, Faculty of Engineering, Kyushu University, Fukuoka 819-0395, Japan

WPI, International Institute for Carbon-Neutral Energy Research (I2CNER), Kyushu University, Fukuoka 819-0395, Japan

\begin{abstract}
The grain size in pure elements (magnesium, aluminum, silicon, titanium, vanadium, chromium, iron, nickel, copper, zinc, germanium, zirconium, niobium, molybdenum, palladium, silver, indium, tin, hafnium, tantalum, gold and lead) after processing by high-pressure torsion (HPT) reaches steady-state levels where the grain size remains unchanged with straining. The steady-state grain sizes decrease by atomic bond energy and related parameters such as specific heat capacity, activation energy for self-diffusion and homologous temperature and are reasonably independent of stacking fault energy. A good correlation exists between the hardness normalized by the shear modulus and grain size normalized by the Burgers vector, indicating that the important factor for strengthening HPT-processed pure metals is the average size of grains having high angles of misorientation.
\end{abstract}

Keywords: High-pressure torsion; Ultrafine-grained microstructure; Severe plastic deformation; Hardness; Grain size

*Corresponding author at: Department of Materials Science and Engineering, Faculty of Engineering, Kyushu University, Fukuoka 819-0395, Japan.

Tel./fax: +81928022992.

E-mail address: kaveh.edalati@zaiko6.zaiko.kyushu-u.ac.jp (K. Edalati). 


\section{Introduction}

Significant grain refinement and resultant high hardness are achieved by processing materials through the application of high-pressure torsion (HPT) [1,2]. In the HPT method a thin disc or ring is held between two anvils under high pressure and severe plastic deformation is imparted by rotating the two anvils with respect to each other [3]. For many pure metals processed by HPT, the hardness and grain size saturate to steady-state levels at high strains where the hardness and grain size remain unchanged with straining [4-19]. The steady-state level is characteristic of each metal and is reasonably the same irrespective of the initial state of the metals before processing [14] and of the processing parameters such as pressure $[16,17]$, provided that no phase transformation occurs $[20,21]$

Earlier papers reported that the steady-state hardness values are represented by several parameters, such as atomic bond energy and related physical parameters such as specific heat capacity and activation energy for self-diffusion [22], shear modulus [21,23,24], homologous temperature [21], grain size [23,24], by specific surface energy for brittle fracture [23] and stacking fault energy [25]. A survey of the literature concluded that little is understood to date regarding the correlations between the steady-state grain size and the atomic bond parameters and the physical properties of pure metals after processing with HPT. Mohamed [26] investigated the correlation between the steady-state grain size and physical parameters for pure metals processed through ball milling. However, this finding cannot be applied directly to HPT-processed pure metals because the mechanism of grain refinement is not the same between ball milling and HPT processing.

This study is thus initiated with two main objectives: one is to investigate the steady-state grain size with respect to atomic bond energy and related parameters such as specific heat capacity, activation energy for self-diffusion, homologous temperature and stacking fault energy, and the other objective is to find a correlation between the hardness and grain size values at the steady state.

\section{Experimental materials and procedures}

In this study, 22 pure elements with different crystal structures (body centered cubic, face centered cubic, hexagonal close packed, diamond cubic and tetragonal), and with steady-state grain size values available either in the present authors' group or in the literature, were selected. It is noted that the correlations between the steady-state hardness and the atomic bond parameters of these elements were reported in an earlier paper [22]. For each metal, purity level, melting temperature $T_{m}$, shear modulus $G$, Burgers vector $b$, atomic bond energy $\Delta H$, specific heat capacity $Q$, activation energy for self-diffusion $Q_{S D}$, stacking fault energy $\gamma_{S F E}$, steady-state grain size $d_{S}$ and steady-state hardness $H V_{S}$, are given in Table 1. Here, $\Delta H$ is the enthalpy required to break all atomic bonds in one cubic meter of pure metal, and $Q$ represents the maximum energy that can be stored in a unit volume of pure metal before it melts. The parameters presented in Table 1 were taken from Refs. [22,26-49].

The values of $H V_{S}$ and $d_{S}$ were used from earlier studies on pure metals using HPT [22,26-38]. In such studies, the as-received specimens were cut to discs $10 \mathrm{~mm}$ in diameter and $0.8 \mathrm{~mm}$-thick, and HPT was carried out on the discs at room temperature. The disc samples were processed under 
a selected pressure in the range $P=1-6 \mathrm{GPa}$ for $N=1 / 8-15$ revolutions with a rotation speed of $\omega$ $=0.2-1.0 \mathrm{rpm}$. For Ti and Zr, the HPT was conducted under a pressure of $2 \mathrm{GPa}$, which is smaller than the critical pressure for $\gamma$-phase formation [20,21]. The samples after HPT were kept at room temperature for $30 \mathrm{~h}$, and this handling was carefully attempted for metals with low melting temperatures, such as $\mathrm{In}, \mathrm{Sn}$ and $\mathrm{Pb}$. Thereafter, the samples were polished to a mirror-like surface, the Vickers microhardness was measured from the center to the edge in eight different radial directions, and the average values were then plotted against the equivalent strain. The hardness in this study was used from the steady state where the hardness remained unchanged with straining. The average grain size values at the steady state were determined using optical microscopy (OM), electron backscatter diffraction (EBSD) analysis or transmission electron microscopy (TEM).

The In, $\mathrm{Sn}$ and $\mathrm{Pb}$ samples were examined using $\mathrm{OM}$, and the $\mathrm{Zn}$ and $\mathrm{Au}$ samples were examined using EBSD analysis, and the average sizes of grains separated by large misorientation angles were determined by the linear intercept method. The other elements were examined using TEM, and the grain size values were obtained by measuring the two orthogonal axes of the bright areas in the dark field images. The low-angle grain boundaries were excluded in the measurements, and the twin boundaries which were present in some elements, such as In and $\mathrm{Pb}$, were considered as grain boundaries. The purity levels used in these studies were $>99.9 \%$ but, nevertheless, despite slight difference in purity levels, the steady-state grain sizes reported in Refs. [22,26-38] are consistent with the values reported concerning HPT-processed pure metals in the other literature [4-12,18,19], as compared in Table 1.

\section{Results and discussion}

Grain sizes at the steady state $\left(d_{S}\right)$ are plotted in Fig. 1 against the atomic bond energy $(\Delta H)$ as attempted in an earlier paper in plotting the steady-state hardness $\left(H V_{S}\right)$ against $\Delta H$ [22]. The values of $d_{S}$ are at the micrometer and submicrometer levels $(>100 \mathrm{~nm})$ in elements with metallic bonding and at the nanometer level $(<100 \mathrm{~nm})$ in $\mathrm{Si}$ and Ge with covalent bonding. Fig. 1 shows that $d_{S}$ decreases significantly with $\Delta H$ in metals with low $\Delta H$ such as $\mathrm{Mg}, \mathrm{Al}, \mathrm{Zn}, \mathrm{In}, \mathrm{Sn}$ and $\mathrm{Pb}$, but decreases gradually with $\Delta H$ in metals with high $\Delta H$. This trend is different from the variation in $H V_{S}$ with respect to $\Delta H$, where $H V_{S}$ increases monotonically with an increase in $\Delta H$ for all $\Delta H$ values [22].

The correlation in Fig. 1 arises for the following reason. The steady state occurs as a result of a balance between several phenomena such as dislocation generation, grain refinement, recovery and recrystallization through atomic diffusion [13-15], all of which are connected to $\Delta H$. The atomic diffusion is significantly suppressed when $\Delta H$ is high because atoms need to break bonds with neighboring atoms to move to adjacent sites. Therefore, it is anticipated that recovery is enhanced and, accordingly, $d_{S}$ increases with a decrease in $\Delta H$. For the metals with low $\Delta H$, a significant recovery occurs even after $\mathrm{HPT}$ at room temperature $[35,36]$ and thus their grain sizes are influenced more significantly by $\Delta H$ compared with metals with high $\Delta H$. Moreover, the atomic diffusion is slow in elements with covalent bonding and, accordingly, $d_{S}$ is smaller compared with elements with metallic bonding. The trend in Fig. 1 thus suggests that there should be a correlation 
between $d_{S}$ and physical parameters related to $\Delta H$ such as the specific heat capacity $(Q)$, the activation energy for self-diffusion $\left(Q_{S D}\right)$ and the homologous temperature $\left(T / T_{m}\right)$. Moreover, since both $d_{S}$ and $H V_{S}$ are correlated with $\Delta H$, there should be some correlations between $d_{S}$ and $H V_{S}$. It is demonstrated in the following that such correlations exist.

Table 1. Purity level, melting temperature $T_{m}$, shear modulus $G$, Burger vector $b$, atomic bond energy $\Delta H$, specific heat capacity $Q$, activation energy for self-diffusion $Q_{S D}$, stacking fault energy $\gamma_{S F E}$, hardness at steady state $H V_{S}$, and grain size at steady state $d_{S}$ for various metals.

\begin{tabular}{|c|c|c|c|c|c|c|c|c|c|c|}
\hline Metal & $\begin{array}{c}\boldsymbol{T}_{\boldsymbol{m}} \\
\mathrm{K} \\
{[39-41]}\end{array}$ & $\begin{array}{c}\boldsymbol{G} \\
\mathrm{GPa} \\
{[39-41]}\end{array}$ & $\begin{array}{c}\boldsymbol{b} \\
\mathrm{nm} \\
{[42]}\end{array}$ & $\begin{array}{c}\Delta \boldsymbol{H} \\
\text { GJ.m }^{-3} \\
{[43]}\end{array}$ & $\begin{array}{c}\boldsymbol{Q} \\
\text { GJ.m-3 } \\
{[39,41]}\end{array}$ & $\begin{array}{c}\boldsymbol{Q}_{S \boldsymbol{D}} \\
\mathrm{kJ} \mathrm{mol}^{-1} \\
{[44,45]}\end{array}$ & $\begin{array}{c}\gamma_{S F E} \\
\text { mJ.m }{ }^{-2} \\
{[46-49]}\end{array}$ & $\begin{array}{c}\text { Purity } \\
\%\end{array}$ & $\begin{array}{c}d_{S} \\
\mu \mathrm{m}\end{array}$ & $\begin{array}{l}\boldsymbol{H} \boldsymbol{V}_{\boldsymbol{S}} \\
\mathrm{GPa} \\
{[22]} \\
\end{array}$ \\
\hline${ }^{12} \mathrm{Mg}$ & 922 & 17.3 & 0.3197 & 10.6 & 1.15 & 138.2 & 125 & $\begin{array}{l}99.9 \\
99.8\end{array}$ & $\begin{array}{c}1.0[27] \\
>1.0[4]\end{array}$ & 0.342 \\
\hline${ }^{13} \mathrm{Al}$ & 933 & 26.2 & 0.2864 & 33.7 & 1.79 & 126.4 & 166 & $\begin{array}{l}99.99 \\
99.99\end{array}$ & $\begin{array}{c}1.9[28] \\
1.5[5]\end{array}$ & 0.313 \\
\hline${ }^{14} \mathrm{Si}$ & 1685 & 39.7 & 0.2352 & 38.0 & 0.72 & 424.0 & & 99.999 & 0.017 [29] & 6.355 \\
\hline${ }^{22} \mathrm{Ti}$ & 1940 & 45.6 & 0.2896 & 44.2 & 5.23 & 169.1 & & $\begin{array}{l}99.4 \\
99.9\end{array}$ & $\begin{array}{c}0.2[31] \\
0.1-0.2[6]\end{array}$ & 2.599 \\
\hline${ }^{23} \mathrm{~V}$ & 2175 & 46.7 & 0.2618 & 61.6 & 7.66 & 308.4 & & 99.9 & $0.33[32]$ & 2.354 \\
\hline${ }^{24} \mathrm{Cr}$ & 2133 & 115 & 0.2498 & 54.8 & 8.61 & 339.1 & & $\begin{array}{c}99.9 \\
99.97\end{array}$ & $\begin{array}{c}0.2[33] \\
<0.5[19]\end{array}$ & 4.756 \\
\hline${ }^{26} \mathrm{Fe}$ & 1809 & 81.6 & 0.2482 & 58.7 & 8.85 & 239.5 & 180 & $\begin{array}{c}99.96 \\
99.9999\end{array}$ & $\begin{array}{c}0.2[34] \\
0.2[7]\end{array}$ & 3.02 \\
\hline${ }^{28} \mathrm{Ni}$ & 1728 & 75 & 0.2492 & 65.1 & 7.26 & 285.1 & 125 & $\begin{array}{c}99.996 \\
99.99\end{array}$ & $\begin{array}{c}0.24[35] \\
0.17[8]\end{array}$ & $\begin{array}{l}3.021 \\
3.500\end{array}$ \\
\hline${ }^{29} \mathrm{Cu}$ & 1357 & 48.3 & 0.2556 & 47.7 & 4.02 & 203.6 & 45 & $\begin{array}{l}99.99 \\
99.99\end{array}$ & $\begin{array}{c}0.37[35] \\
0.4[9]\end{array}$ & 1.298 \\
\hline${ }^{30} \mathrm{Zn}$ & 693 & 41.9 & 0.2665 & 14.3 & 1.09 & 91.7 & 140 & 99.99 & 5.1 [35] & 0.362 \\
\hline${ }^{32} \mathrm{Ge}$ & 1210 & 29.6 & 0.2449 & 27.6 & 1.34 & 318.0 & & 99.999 & $0.024[30]$ & 2.986 \\
\hline${ }^{40} \mathrm{Zr}$ & 2125 & 35 & 0.3179 & 43.3 & 3.94 & 113.0 & 240 & $\begin{array}{l}99.9 \\
99.8\end{array}$ & $\begin{array}{l}0.2[36] \\
0.2[10]\end{array}$ & 2.532 \\
\hline${ }^{41} \mathrm{Nb}$ & 2740 & 37.5 & 0.2864 & 67.2 & 7.01 & 401.9 & & $\begin{array}{c}99.9 \\
99.99\end{array}$ & $\begin{array}{c}0.24[33] \\
0.113[18]\end{array}$ & 2.354 \\
\hline${ }^{42} \mathrm{Mo}$ & 2888 & 125.6 & 0.2725 & 70.0 & 9.17 & 464.7 & & $\begin{array}{l}99.9 \\
99.9\end{array}$ & $\begin{array}{l}0.34[32] \\
0.19[11]\end{array}$ & 6.669 \\
\hline${ }^{46} \mathrm{Pd}$ & 1825 & 43.6 & 0.2751 & 42.7 & 5.36 & 266.3 & 180 & $\begin{array}{c}99.95 \\
---\end{array}$ & $\begin{array}{l}0.22[35] \\
0.24[12]\end{array}$ & 2.127 \\
\hline${ }^{47} \mathrm{Ag}$ & 1234 & 27 & 0.2889 & 27.7 & 2.59 & 181.7 & 16 & 99.99 & 0.48 [37] & 0.941 \\
\hline${ }^{49} \mathrm{In}$ & 430 & 3.7 & 0.3251 & 15.5 & 0.24 & 78.5 & & 99.999 & $320[35]$ & 0.014 \\
\hline${ }^{50} \mathrm{Sn}$ & 505 & 18.4 & 0.3022 & 18.6 & 0.51 & 105.1 & & 99.99 & $135[35]$ & 0.068 \\
\hline${ }^{72} \mathrm{Hf}$ & 2500 & 56 & 0.3127 & 45.4 & 5.26 & 174.2 & & 99.99 & 0.18 [38] & 3.481 \\
\hline${ }^{73} \mathrm{Ta}$ & 3253 & 69 & 0.2856 & 71.7 & 8.22 & 413.2 & & 99.9 & 0.18 [33] & 4.132 \\
\hline${ }^{79} \mathrm{Au}$ & 1336 & 27.7 & 0.2884 & 33.0 & 3.11 & 176.6 & 32 & 99.999 & $0.52[37]$ & 0.804 \\
\hline${ }^{82} \mathrm{~Pb}$ & 600 & 5.6 & 0.3500 & 10.7 & 0.48 & 109.1 & 24.5 & 99.999 & $100[35]$ & 0.051 \\
\hline
\end{tabular}

Figs. 2 and 3 show the variations in $d_{S}$ with respect to two well-known atomic bond parameters $Q$ and $Q_{S D}$, respectively. As expected, $d_{S}$ has good correlation with $Q$ and $Q_{S D}$. Because $Q$ and $Q_{S D}$ are increasing functions of $\Delta H, d_{S}$ decreases significantly with increasing $Q$ and $Q_{S D}$ in metals with low $\Delta H$, and decreases gradually as a function of $Q$ and $Q_{S D}$ in metals with high $\Delta H$, as in Fig. 1 . Since the stored energy in the materials is increased by the grain refinement, and $Q$ represents the maximum energy that can be stored in a unit volume of solid material, it is very reasonable to 
establish a correlation between $d_{S}$ and $Q$. It should be noted that the data points of Si and Ge deviate from the relations in Figs. 1-3 because Si and Ge are formed with strong covalent bonding.

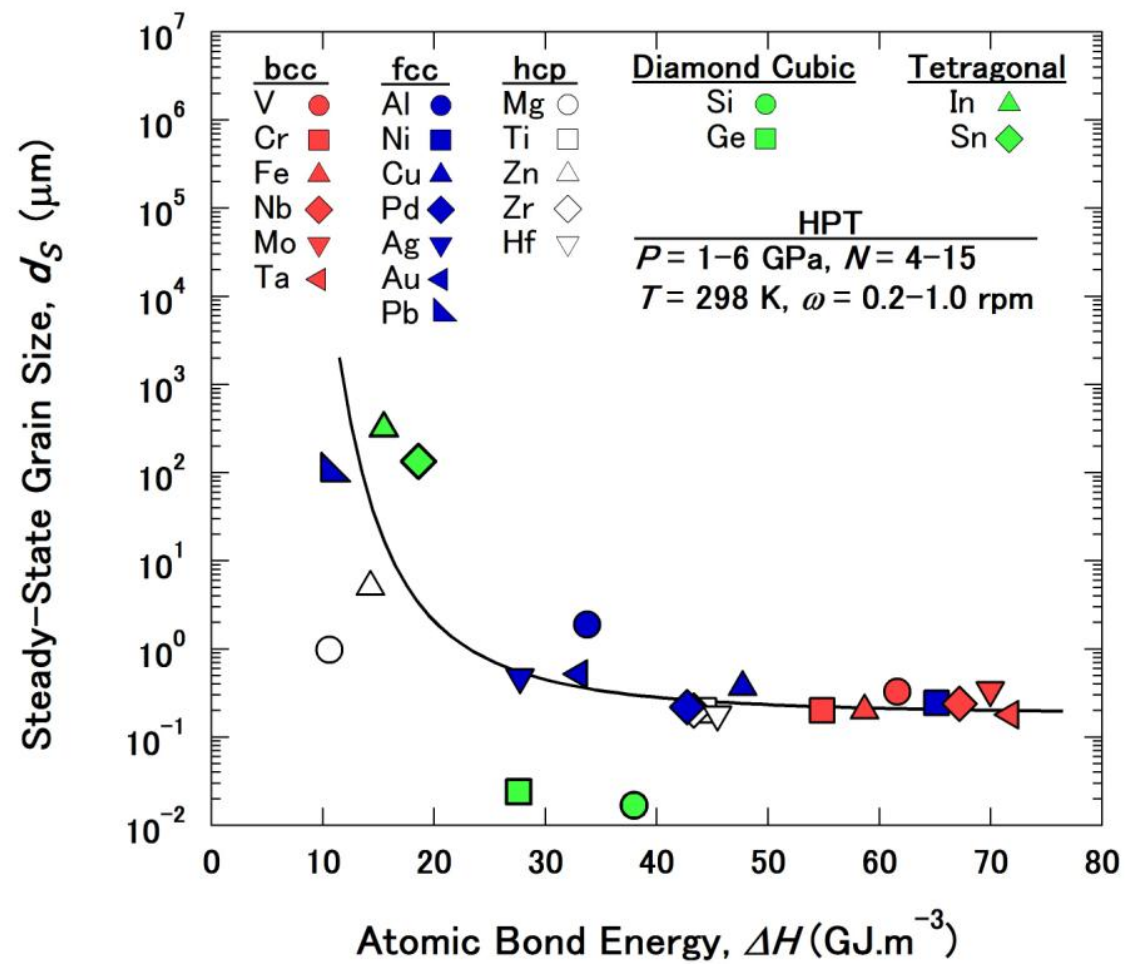

Fig. 1. Plots of $d_{S}$ against $\Delta H$.

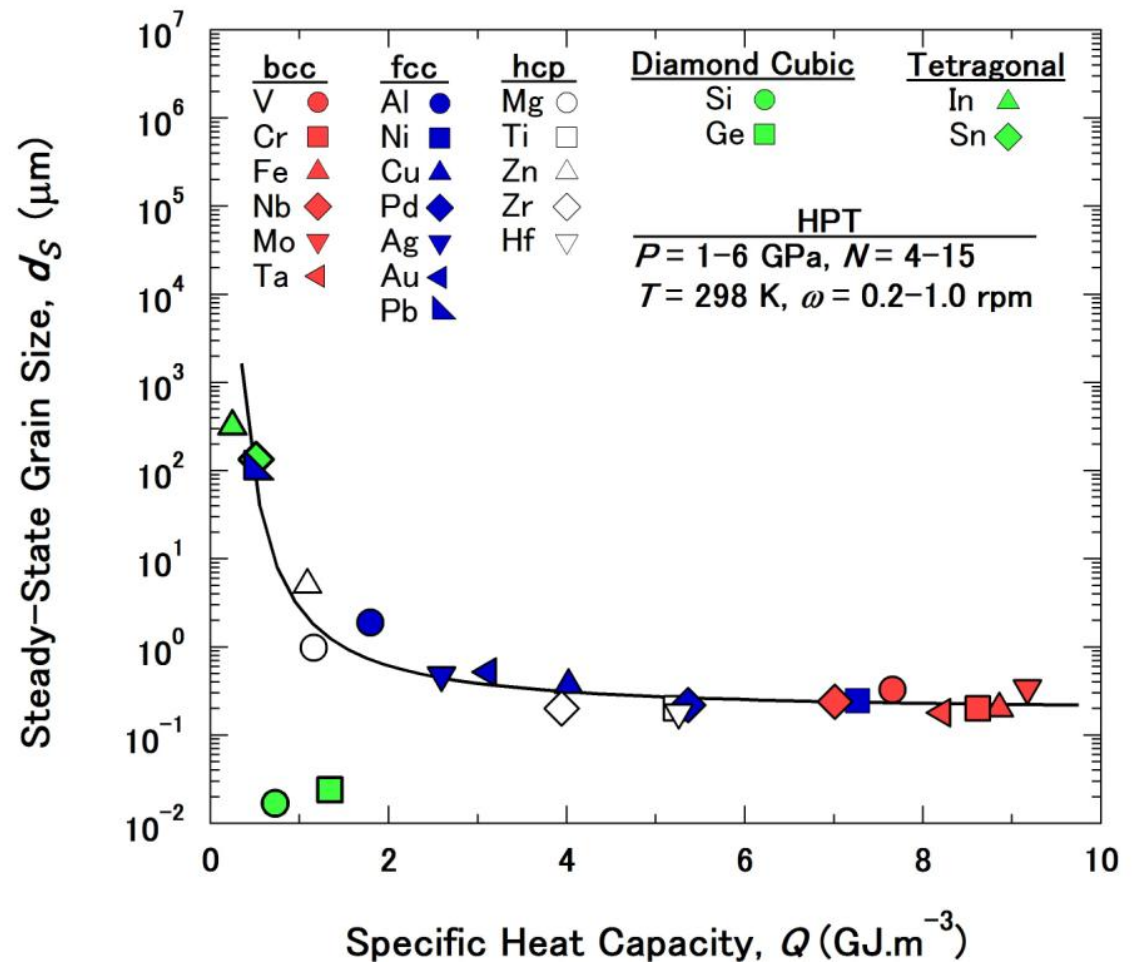

Fig. 2. Plots of $d_{S}$ against $Q$. 


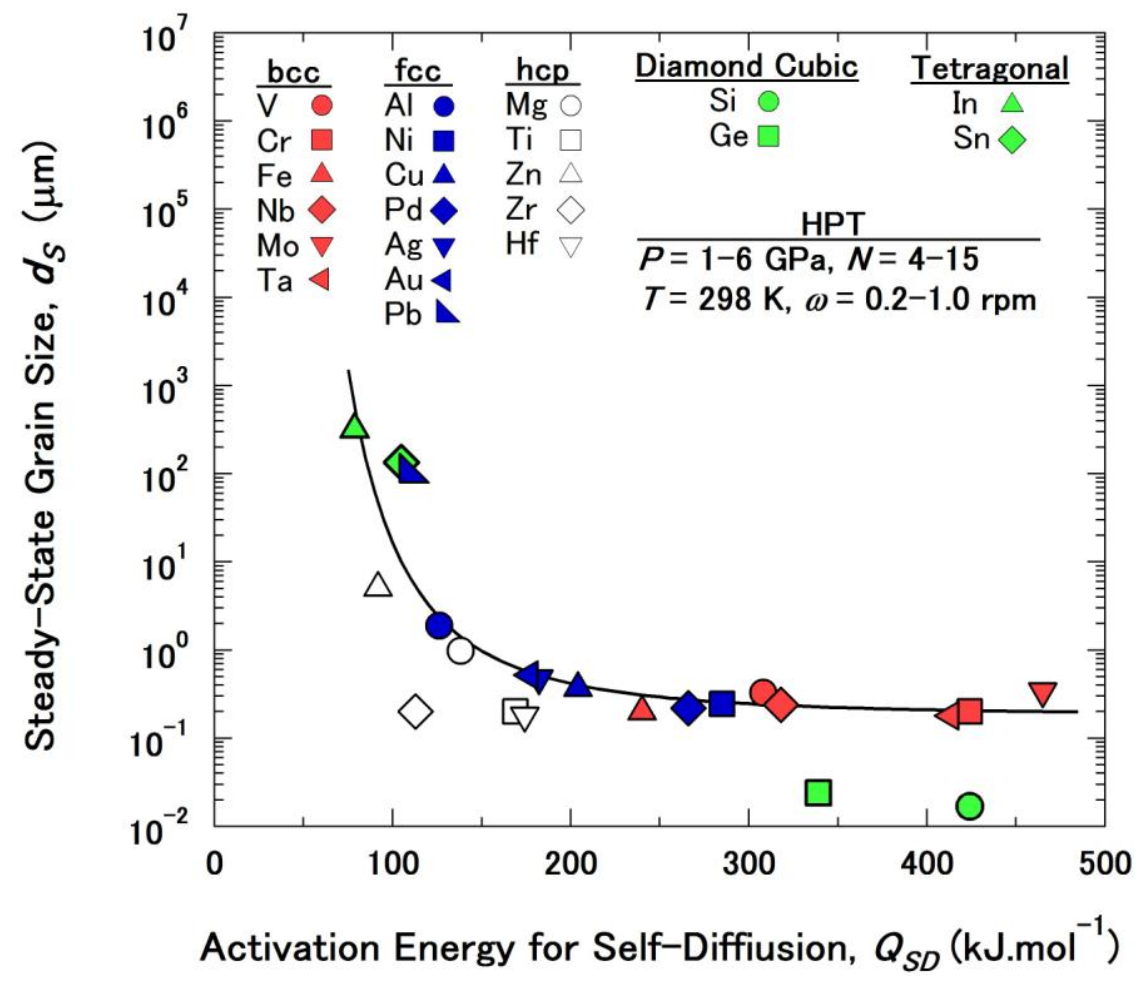

Fig. 3. Plots of $d_{S}$ against $Q_{S D}$.

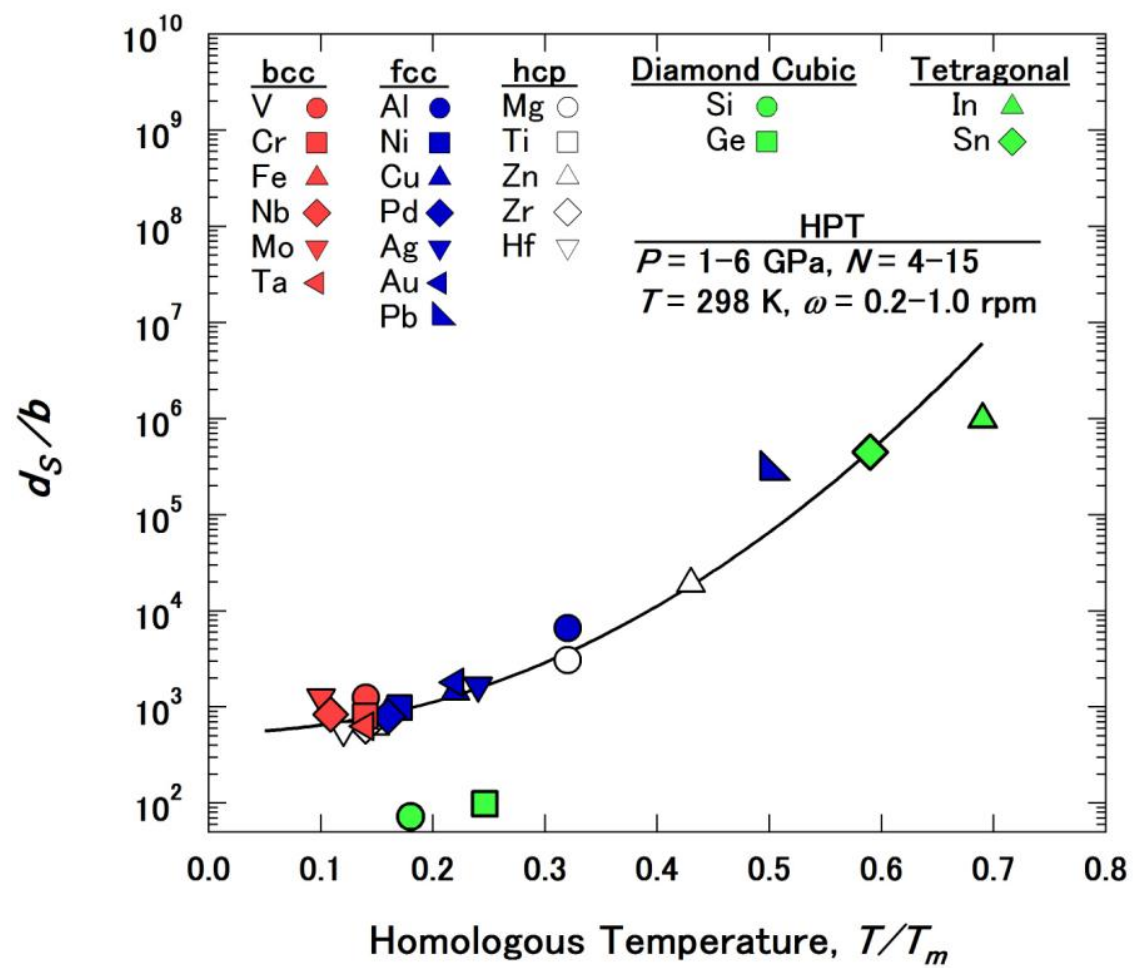

Fig. 4. Plots of $d_{S} / b$ against $T / T_{m}$. 


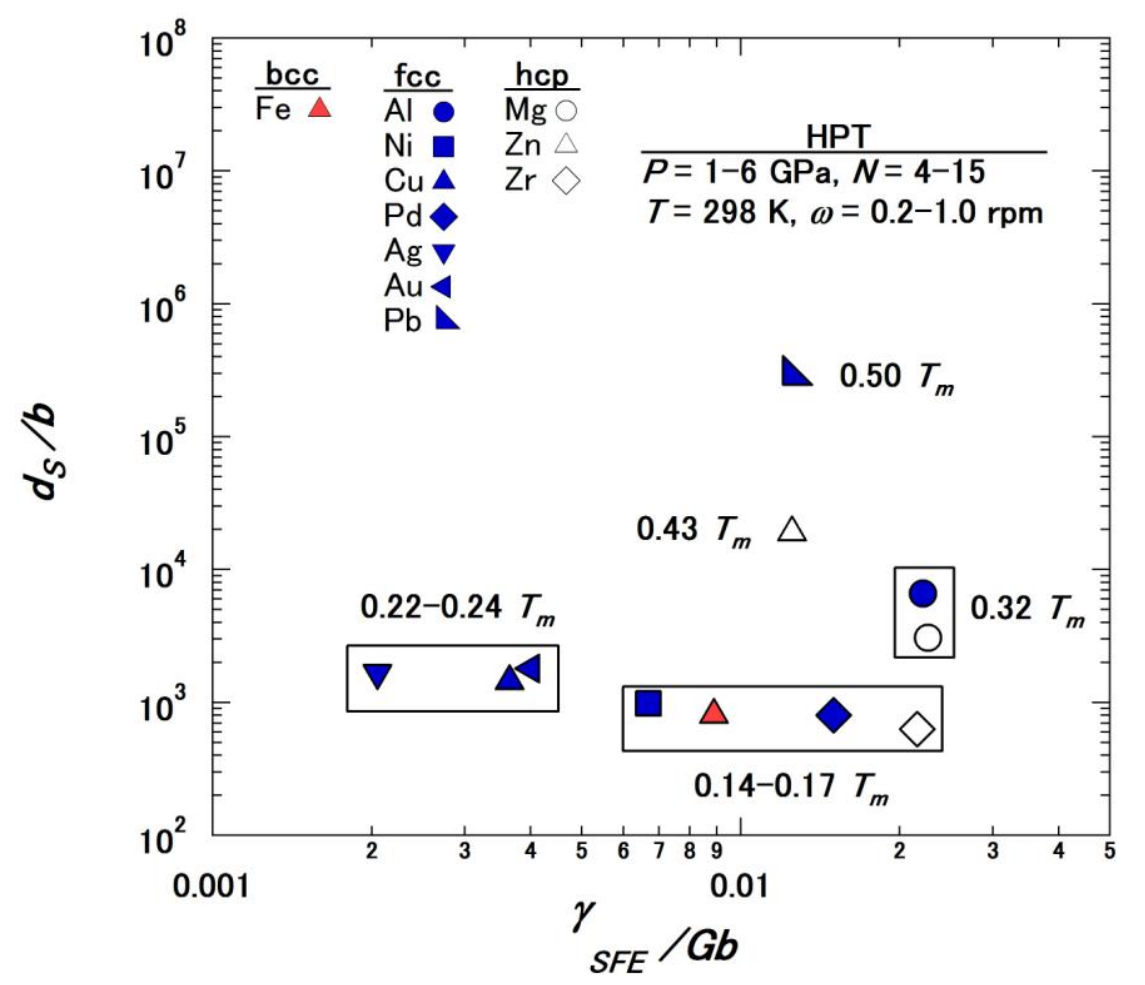

Fig. 5. Plots of $d_{S} / b$ against $\gamma_{S F E} / G b$.

The values of $d_{S}$ are normalized by Burgers vector $(b)$ and plotted as a function of $T / T_{m}$ and $\gamma_{S F E} / G b$ ( $\gamma_{S F E}$ is the stacking fault energy, $G$ is the shear modulus) in Figs. 4 and 5, respectively. This normalization was attempted because the expression as $d_{S} / b$ has the merit of revealing intrinsic differences and similarities between pure metals [50,51]. Furthermore, it is well known that $T / T_{m}$ and $\gamma_{S F E} / G b$ are controlling factors for dislocation mobility through cross-slip and climb mechanisms in pure metals $[50,51]$. The higher value of $T / T_{m}$ promotes the dislocation recovery, and the microstructure evolves much faster when $\gamma_{S F E} / G b$ is high. It is apparent from Fig. 4 that $d_{S} / b$ values increase exponentially with increasing $T / T_{m}$, except the deviations for $\mathrm{Si}$ and Ge. Close inspection of Fig. 4 shows that the effect of temperature on the steady-state grain size is less pronounced at low homologous temperatures. This is a natural consequence of the fact that the temperature always affects the atomic diffusion, the microstructural evolution and the Zener-Hollomon parameter through the exponential forms [45,46,50]. Inspection of Fig. 5 shows that $d_{S} / b$ is almost independent of $\gamma_{S F E} / G b$ as far as the data are evaluated at a given $T / T_{m}$. The present results are not consistent with the report by Mohamed in ball-milled metals [26] and with the reports in HPT-processed $\mathrm{Pd}-\mathrm{Ag}$ alloys [12], $\mathrm{Cu}-\mathrm{Zn}$ alloys [52], $\mathrm{Cu}-\mathrm{Al}$ alloys [53] and $\mathrm{Al}-\mathrm{Mg}$ alloys [54], where the grain size increases with increasing $\gamma_{S F E} / G b$. Inspection of Refs. [12,52-54] indicates that the grain size decreases with an increases in the fraction of solute atoms in all selected alloys. Therefore, the contradiction arises because of the effect of homologous temperature in Ref. [26] and of the effect of solute atoms and twins in Refs. [12,52-54].

The values of $H V_{S}$ are normalized by $G$ and are plotted against $d_{S} / b$ in Fig. 6 . It is apparent that all data points lie reasonably on a single curve in Fig. 6 , and $H V_{S} / G$ decreases monotonically with 
increasing $d_{S} / b$. Inspection of Fig. 6 shows that the following relationship holds, while excluding the three metals as $\mathrm{In}, \mathrm{Sn}$ and $\mathrm{Pb}$ with low $\Delta H$, which are considered to be influenced by softening due to recovery of dislocations during or after HPT.

$$
\frac{H V_{S}}{G}=3\left(\frac{d_{S}}{b}\right)^{-0.6}
$$

the grain size exponent of 0.6 is closer to $1 / 2$ as expected from the Hall-Petch relationship. This indicates that the important factor for strengthening the HPT-processed pure metals is the size of grains with high angles of misorientation.

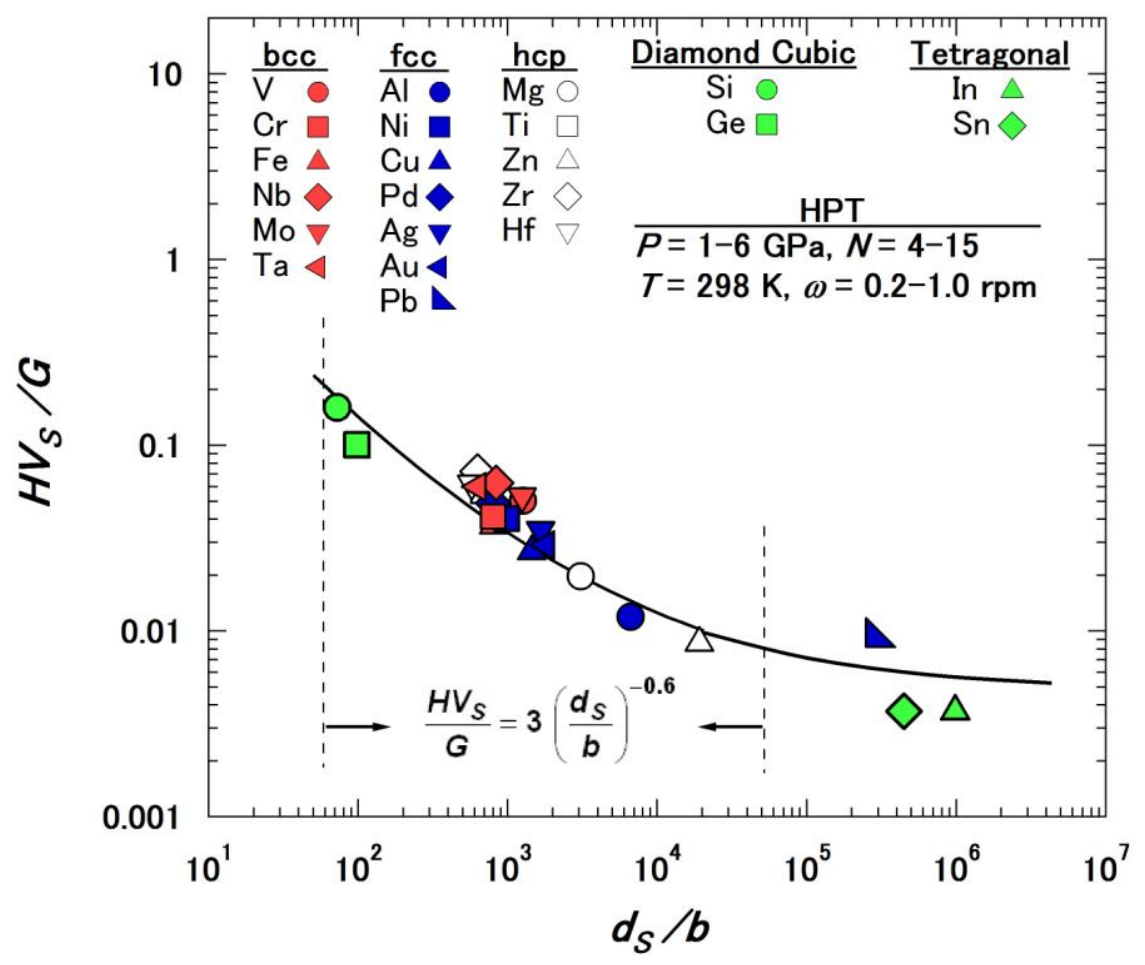

Fig. 6. Plot of $H V_{S} / G$ against $d_{S} / b$.

The form of Eq. (1) is similar to a well-known relationship in conventional creep that the subgrain size $(d)$ is dependent on the shear stress $(\tau)$ in polycrystalline materials as $[51,55,56]$

$$
\frac{\tau}{G}=A\left(\frac{d}{b}\right)^{-n}
$$

where $A$ and $n$ are constants with values 0.1 and 1, respectively. Mohamed [26] suggested that the mechanisms for grain refinement by ball milling and creep are similar, and Kawasaki et al. [57] reported that the experimental data for superplastic alloys processed by equal channel angular pressing are well consistent with the predictions of the deformation map. However, $n=1$ for creep relationship and $n=0.6$ in Eq. (1) indicate that Eq. (2) yields hardness values which are smaller than the experimental values in Fig. 6. Theoretically, $n=1$ is achieved when all dislocations are assumed to be at the dislocation cell walls or subgrain boundaries [24,58]. The difference between Eqs. (1) and (2) arises for two reasons: first, there are many dislocations not only at the grain boundaries, but also within the grains in the HPT-processed materials [15,31,34]; and second, most 
of dislocations participate in the formation of subgrain boundaries or low-angle grain boundaries in creep [24,55], whereas the grain boundaries are in high angles of misorietation in HPT-processed materials [1,2] and the high-angle grain boundaries block the dislocation motion. This yields hardness values which are higher than those in creep.

At the steady state for severe plastic deformation (SPD) processing, the grain size and hence hardness remain constant because of the balance between dislocation accumulation and grain refinement, on the one hand, and annihilation of dislocations and destruction of grain boundaries, on the other. Some studies reported that the steady state in SPD processing is reached by annihilation of dislocations by dynamic recovery [26,59,60], and some studies supported that the steady state can be attained by dynamic recrystallization [9,61]. Furthermore, recent studies by Pippan et al. $[62,63]$ suggested that grain boundary migration is a process necessary for forming a steady-state microstructure, and another paper by Mishra et al. [64] reported that the steady state is a consequence grain boundary movement of grain rotation. Because certain fractions of grains were free of dislocations at the steady state, as reported earlier [15,34], it was concluded that the dynamic recrystallization may be a dominant mechanism at the steady state [15,34]. The present analysis has shown that the steady-state grain size is independent of the stacking fault energy, as in Fig. 5, but increases exponentially with the homologous temperature, as in Fig. 4. It is well known that stacking fault energy is a key parameter in dynamic recovery [50,51] and, therefore, the present study suggests that the dynamic recrystallization and the grain boundary migration can be more appropriate mechanisms for the steady state when compared to dynamic recovery. It is not certain from the present study that grain rotation can be a process contributing to the microstructural development during dynamic recrystallization at the steady state, as this contribution cannot be evaluated from the present analysis in an explicit way.

\section{Conclusions}

The extent of grain refinement for pure elements after processing with HPT is controlled by the type of atomic bonds (metallic or covalent) as well as by atomic bond energy $(\Delta H)$. The grain size values at the steady state $\left(d_{S}\right)$ are at the micrometer and submicrometer levels in elements with metallic bonding and at the nanometer level in elements with covalent bonding. The $d_{S}$ value decreases with $\Delta H$ and related parameters such as the specific heat capacity $(Q)$, the activation energy for self-diffusion $\left(Q_{S D}\right)$ and the homologous temperature $\left(T / T_{m}\right)$, but $d_{S}$ is almost independent of the stacking fault energy $\left(\gamma_{S F E}\right)$ as far as the data are evaluated at a given $T / T_{m}$. Good correlations between the steady-sate hardness $\left(H V_{S}\right)$ and $d_{S}$ are found when $H V_{S} / G$ is plotted against $d_{S} / b$, indicating that the average size of grains having high angles of misorientation is the important factor for strengthening HPT-processed pure metals.

\section{Acknowledgments}

One of the authors (K.E.) thanks the Islamic Development Bank (IDB) for a doctoral scholarship and the Japan Society for Promotion of Science (JSPS) for a postdoctoral scholarship. This work was supported in part by the Light Metals Educational Foundation of Japan, in part by a 
Grant-in-Aid for Scientific Research from the MEXT, Japan, in Innovative Areas "Bulk Nanostructured Metals" and in part by Kyushu University Interdisciplinary Programs in Education and Projects in Research Development (P\&P).

\section{References}

[1] Valiev RZ, Islamgaliev RK, Alexandrov IV. Prog Mater Sci 2000;45:103.

[2] Zhilyaev AP, Langdon TG. Prog Mater Sci 2008;53:893.

[3] Bridgman PW. Phys Rev 1935;48:825.

[4] Bonarski BJ, Schafler E, Mingler B, Skrotzki W, Mikulowski B, Zehetbauer MJ. J Mater Sci 2008;43:753.

[5] Kawasaki M, Ahn B, Langdon TG. J Mater Sci 2010;45:4583.

[6] Todaka Y, Umemoto M, Yamazaki A, Sasaki J, Tsuchiya K. Mater Trans 2008;49:47.

[7] Descartes S, Desrayaud C, Rauch EF. Mater Sci Eng A 2011;528:3666.

[8] Zhilyaev AP, Lee S, Nurislamova GV, Valiev RZ, Langdon TG. Scripta Mater 2001;44:2753.

[9] Hebesberger T, Stuwe HP, Vorhauer A, Wetscher F, Pippan R. Acta Mater 2005;53:393.

[10] Podolskiy AV, Bonarski B, Setman D, Mangler C, Schafler E, Tabachnikova ED, et al. Mater Sci Forum 2011;667-669:433.

[11] Kolobov YR, Kieback B, Ivanov KV, Weissgaerber T, Girsova NV, Pochivalov YI, et al. Int J Refract Met Hard Mater 2003;21:69.

[12] Kurmanaeva L, Ivanisenko Y, Markmann J, Kubel C, Chuvilin A, Doyle S, et al. Mater Sci Eng A 2010;527:1776.

[13] Xu C, Horita Z, Langdon TG. Acta Mater 2007;55:203.

[14] Hafok M, Pippan R. Phil Mag 2008;88:1857.

[15] Edalati K, Fujioka T, Horita Z. Mater Sci Eng A 2008;497:168.

[16] Wetscher F, Vorhauer A, Pippan R. Mater Sci Eng A 2005;410-411:213.

[17] Edalati K, Horita Z. Mater Trans 2010;51:1051.

[18] Popova EN, Popov VV, Romanov EP, Pilyugin VP. Phys Met Metall 2006;101:52.

[19] Wadsack R, Pippan R, Schedler B. Fusion Eng Des 2003;66-68:265.

[20] Kilmametov AR, Khristoforova AV, Wilde G, Valiev RZ. Z Kristallogr Suppl 2007;26:339.

[21] Perez-Prado MT, Gimazov AA, Ruano OA, Kassner ME, Zhilyaev AP. Scripta Mater 2008;58:219.

[22] Edalati K, Horita Z. Scripta Mater 2011;64:161.

[23] Divinski SV, Padmanabhan KA, Wilde G. Mater Sci Forum 2011;667-669:283.

[24] Estrin Y, Kim HS. J Mater Sci 2007;42:1512.

[25] Zhao YH, Zhu YT, Liao XZ, Horita Z, Langdon TG. Appl Phys Lett 2006;89:121906.

[26] Mohamed FA. Acta Mater 2003;51:4107.

[27] Edalati K, Yamamoto A, Horita Z, Ishihara T. Scripta Mater 2011;64:880.

[28] Edalati K, Ito Y, Suehiro K, Horita Z. Int J Mater Res 2009;100:1668.

[29] Islamgaliev RK, Kuzel R, Mikov SN, Igo AV, Burianek J, Chmelik F, et al. Mater Sci Eng A 1999;266:205. 
[30] Islamgaliev RK, Kuzel R, Obraztsova ED, Burianek J, Chmelik F, Valiev RZ. Mater Sci Eng A 1998;249:152.

[31] Edalati K, Matsubara E, Horita Z. Metall Mater Trans A 2009;40:2079.

[32] Lee SW, Edalati K, Horita Z. Mater Trans 2010;51:1072.

[33] Lee SW, Horita Z, unpublished work.

[34] Edalati K, Fujioka T, Horita Z. Mater Trans 2009;50:44.

[35] Edalati K, Horita Z. Mater Sci Eng A 2011;528:7514.

[36] Edalati K, Horita Z, Yagi S, Matsubara E. Mater Sci Eng A 2009;523:277.

[37] Matsunaga H, Horita Z. Mater Trans 2009;50:1633.

[38] Edalati K, Horita Z, Mine Y. Mater Sci Eng A 2010;527:2136.

[39] Buch A. Short handbook of metal elements properties and elastic properties of pure metals. 3rd ed. Warasaw: Krzysztof Biesaga; 2005.

[40] Buch A. Pure metals properties, a scientific-technical handbook. Metals Park/London and Tel Aviv: ASM International/Freund Publishing House; 1999.

[41] Metals Handbook. Properties and selection of nonferrous alloys and special-purpose materials, vol. 2. Ohio: ASM International, Metals Park; 1990.

[42] Cullity BD. Elements of X-ray diffraction. 2nd ed. London: Addison-Wesley; 1978.

[43] Emsley J. The elements. 2nd ed. Oxford: Clarendon Press; 1991.

[44] Mehrer H. Numerical data and functional relationships in science and technology, diffusion in solid metals and alloys, vol. 26. Berlin: Springer; 1990.

[45] Shewmon P. Diffusion in solids. 2nd ed. Pennsylvania: The Minerals, Metals \& Materials Society; 1989.

[46] Hirth JP, Lothe J. Theory of dislocations. 2nd ed. New York: McGraw-Hill; 1968.

[47] Hartley CS. Phil Mag 1966;14:7.

[48] Sastry DH, Luton MJ, Jonas JJ. Phil Mag 1974;30:115.

[49] Jossang T, Hirth JP. Phil Mag 1966;13:657.

[50] Frost HJ, Ashby MF. Deformation-mechanism maps, the plasticity and creep of metals and ceramics. Oxford: Pergamon Press; 1982.

[51] Bird JE, Mukherjee AK, Dorn JF. Correlations between high temperature creep behavior and structure. Haifa: Israel Universities Press; 1969.

[52] Zhao YH, Zhu YT, Liao XZ, Horita Z, Langdon TG. Mater Sci Eng A 2005;410-411:188.

[53] An XH, Lin QY, Wu SD, Zhang ZF, Figueiredo RB, Gao N, et al. Scripta Mater 2011;64:954.

[54] Morishige T, Hirata T, Uesugi T, Takigawa Y, Tusjikawa M, Higashi K. Scripta Mater 2011;64:355.

[55] Langdon TG. J Mater Sci 2006;41:597.

[56] Langdon TG. Acta Metall Mater 1994;42:2437.

[57] Kawasaki M, Lee S, Langdon TG. Scripta Mater 2009;61:963.

[58] Toth LS, Molinari A, Estrin Y. J Eng Mater Technol 2002;124:71.

[59] Stuwe HP. Acta Metall 1965;13:1337.

[60] Zehetbauer M. Acta Metall Mater 1993;41:589. 
[61] Hansen N. Metall Mater Trans A 2001;32:2917.

[62] Pippan R, Scheriau S, Taylor A, Hafok M, Hohenwarter A, Bachmaier A. Annu Rev Mater Res 2010;40:319.

[63] Hafok M, Pippan R. Int J Mater Res 2010;101:1097.

[64] Mishra A, Kad BK, Gregori F, Meyers MA. Acta Mater 2007;55:13. 